\title{
The Fundamental and Philosophical Values of Javanese Culture in The Decorative Art of Wuwungan in Kudus Traditional House
}

\author{
Arif Suharson $^{1 *}$ Dharsono $^{2}$ Bambang Sunarto ${ }^{2}$ Nanik Sri Prihatini ${ }^{2}$ \\ 1. Arts Doctoral Program, Indonesian Institute of the Arts Surakarta, Central Java, Indonesia \\ 2. Postgraduate of the Indonesian Institute of the Arts Surakarta, Central Java, Indonesia \\ * E-mail of the corresponding author: arifsuharson318@gmail.com
}

\begin{abstract}
The decorative art of wuwungan developed by the Javanese people has been inherited over the generations. With its unique characteristics, such a decorative art has some established aesthetic, symbolic, and philosophical values. The decorative art of wuwungan applied in the rooftop of the traditional house of Kudus has a unique shape with some sulur-suluran ornamented with some uniquely fragmented glass. Therefore, such visualization is interesting for a scientific study. This study employs the qualitative description method using the historical, architectural, philosophical, and aesthetic approaches. The result of the study will be the concept of the shape and philosophy of the decorative art of wuwungan in the traditional house of Kudus that represents noble values of traditional Javanese a local identity and culture to be reserved as a national cultural asset that underlies the development of civilized society in Indonesia.
\end{abstract}

Keywords: Wuwungan, Aesthetics, Decorative Art, Traditional House of Kudus

DOI: $10.7176 /$ ADS/93-06

Publication date:June $30^{\text {th }} 2021$

\section{Introduction}

Indonesia has various kinds of traditional house architectures with different ornamental shapes and arts, particularly for residential houses. When we observe carefully, the distinguishing features of Indonesian traditional houses are the shape and the decoration of the rooftop that can become the local genius. This is apparent in such traditional houses as in Dayak Kalimantan, Tongkonan Sulawesi, Rumah Gadang in Padang West Sumatera, Bali, and Java. In addition, the design of customary house in Minangkabau, Indonesia is influenced by customs and regional factors (Ismail, Yunus and Surat 2016). Rumah Aceh has the patterns, styles and motifs of ornamentation used for house decorating that prior to the colonial era (Dhuhri, 2018).

Certainly, there are still many other unique decorative arts of rooftop in other places. They all enrich the cultural assets of Indonesia. The application of such ornamental decorative arts in particular space and place will have to comply with the prevailing norms, fundamentals, and philosophical values.

The Javanese house has various types and shapes with different decorative arts that imply different purpose and goal. Javanese house is loaded with ethical and aesthetic values (Utomo \& Subiyantoro, 2012). Such decorative ornaments derive from the local environment. Such is also the case of the decorative arts applied in particular parts of Javanese house. Different ornaments in Javanese houses have different shapes and values. In Javanese life, the royal palace is the cosmic center. A house is a naturally created environment commonly called a cosmos. Therefore, a house is a manifestation of the cosmos for the dwellers. Cosmos also refers to a space. Therefore, it is closely associated with the persons who live in it. Cosmologically, the development of Javanese house consistently holds the Javanese cultural values characterized by a mystical life (Mulder, 1970). Such this mystical life influences the mindset and acts of the community. Even, the cosmological life has been shifted to the house interpretation in which the whole Javanese residential system reflects the natural environment, which depends very much on some natural signs.

Javanese culture derives from the cognitive, affective, and intentional process in the Javanese ethnic's life. It evolves in a continuous continuum of time in anticipation of the ongoing change of time. Some propositions have suggested that the life of Javanese people is very complicated and complex. However, they successfully simplify their need of life which normally takes some time for them to meet such a need. Javanese people simplify their needs in such a way that they classify the needs into only three kinds. They are pangan (food), sandang (cloth), and papan (shelter). When they are elaborated, they will have both physical, mental, material, and spiritual aspects. They may be real or symbolic (Ronald, 2005). 
The decorative art of wuwungan is applied on the highest rooftop above the blandar penuwun (the main pillar). Such a rooftop covers the upper roof tile arrangement and keeps the dust and rain water from entering the house. To understand better about the existence of the decorative art of wuwungan, particularly in the northern coastal area, it is necessary to identify the history of Javanese traditional house. Most houses in the northern coastal area were built in 1810 . The houses used to symbolize a pride for the owners. The buildings were developed by the people who were economically rich. Beside that, they were developed to realize the collective awareness about the importance of permanent mosque development. In the 15th century, Chinese Muslims in the northern coastal area developed their own mosques (Lombard, 2000). At the same time, a number of indigenous local traders, whose business grew significantly, developed their Javanese traditional houses to represent their collective identity.

The Javanese traditional house in the hinterland (Nagarigung) the application of the decorative art of wuwungan is based on the prevailing royal norms or regulations which requires the application of wuwungan above the blandar penuwun. Such norms imply a good wish (pepiling) and expectation of the dwellers. When blandar penuwun was constructed, a ceremony was conducted to express gratitude to God the Almighty. White cotton cloth and golden nails were put on the blandar penuwun to symbolize the holy intent to have religious services to God the Almighty. The decorative art of wuwungan represents and symbolizes expectations and prayers. They were symbolized in the royal crown implying the spirit of such warriors or heroes (pamomong) as Bima, Kresna, Semar, Gunungan, and other figures popularly known in the puppet show literature. Other symbols include such strong animals as lion, cock, and elephant. They all symbolize an expectation of the house owner that the symbols will keep them from any visible and invisible calamity and danger.

The decorative arts of wuwungn in the coastal areas of Demak, Kudus, Jepara, Lasem, and Pati have different and unique shapes and styles. They were all took the shapes of leaves, trunks, roots, flowers, and spirals because in Islamic teaching, decorative arts depicting the living creatures are prohibited. The people of Kudus and beyond hold Islamic religion and therefore, they do not have such kinds of art. Accordingly, they decorate their rooftop with such shapes as gunungan and gelung supit urang ornamented with glass fragments. They look like a royal crown. They also decorate the 4 sides of the pillars of blandar penuwun with the decorative art of wuwungan in the shape of the jengger (cock's comb). This style is different from that in the hinterland of Java.

In Javanese tradition, the development of a house is inseparable from the ornament or decoration of the rooftop. Many houses in Demak Central Java have such ornaments as a series of terracotta or earthenware in the shapes of popular puppet figures. Or else, the ornaments take the shape of gunungan (mountain) surrounded by various kinds of plants. Because the terracotta or earthenware are ornamented with glass mosaics, in the midday they will reflect a glowing shine (Soekiman, 2000).

Wuwungan Kudus is very unique and exclusively has some fundamental values which are absent in other regions of Java. The decorative art of wuwungan takes the shape of sulur-sulur. In the central part of the top there is a wuwungan rojo and a pengapit ornamented with some glass mosaics. Therefore, they look like a gunungan (mountain) or a royal crown. On the four sides towards the top of the pillars of blandar penuwun there is another decorative art known as wuwungan jengger or wuwungan cekak. At the wuwungan jengger there is no glass mosaics. It is locked with the wuwungan bulusan at the lowest side. The corners of the 4 sides are not ornamented with glass mosaics either. Therefore, the fragmented triangular clear glass is only applied as the ornament of the top of the blandar penuwun.

The development of a building is not independent of external influences. Instead, the development is influenced by foreign and past cultures. In addition, it is also influenced by the contemporary culture due to the acculturation process. Javanese culture is open to the influence of other cultures. It assimilates with other cultures through an acculturation process. However, Javanese culture reserves its local genius. The life of Javanese people is full of implicit values or sanepa (figurative speech or symbol). They adopt them as the pepiling (reminder) and lessons for the next generation through the creation of art works.

\section{Methods}

This study seeks to find and provide qualitative explanations, so that the method used is qualitative. This method avoids mathematical calculations, because what is sought is the value of 'value' that arises from the object of study that is special, even very specific, unique and always contains full action meaning. Qualitative research is often a study of the meaning contained in the object of research, it can also be a case study or multi-case in field research. Research conducted internally is as one of the study of the scope of the field of fine arts, especially craft art that utilizes natural materials around the community with ornamentation forms created by the 
philosophical values contained in it. This will have a sustainable impact, so that the wealth of local traditions will continue to run as a characteristic of local geniuses that enrich the nation's culture. The results can be used as information and reference about craft art for academic and non-academic scholars, as well as a contribution to regional development, in an effort to maintain local identity and preservation of the nation's cultural arts.

This research in principle uses descriptive methods of analytics. Descriptive methods of analytics are used as a method to decipher objects while analyzing them. The description method is more widely used in data collection, while the analysis method in the analysis of the data itself. The description of the analytics basically describes something as it is according to the data and the facts. The data and facts are then parsed, classified, and analyzed to obtain a detailed picture, thus drawing accountable conclusions. By using these methods together, it will find the concept of form against the hidden intrinsic values of the objects studied and can provide an understanding of the noble teachings of ethics in Javanese culture to the maximum by using historical, architectural, philosophical, and aesthetic methods.

Data analysis is an effort to systematically search and organize the records of literature studies, observations, interviews, and others arranged into the form of research results in accordance with established theories. The steps in applying the analysis method are: 1) data reduction; 2) classification of data; 3) display data; and 4) interpret and interpret and draw conclusions (Nasution, 2005). In a shorter explanation R.M. Soedarsono suggested that in analyzing qualitative data after the data is collected, then selected well according to the needs. After that critically explanted all the necessary information (Soedarsono, 1999).

\section{Discussion}

The philosophical values of Javanese people influence their way of life in attempt of obtaining life perfection. Javanese people base their attitudes and behaviors on such philosophical values. The Javanese philosophical and cultural values undergo development and improvement. The existence will have impact on people's fundamental comprehension and accordingly is adapted and adjusted to the ongoing development. Javanese culture is a historically established way of life. It is likely to be adopted by all or part of the society. By this definition, it is clear that culture is a voluntary likelihood without any sanction or coercion for the people to adopt it. Therefore, naturally, there will be various interpretation of culture. The Javanese believe that every move is in the power of God and everything is determined absolutely by God and everything in his life is always aligned with the anger of God and the universe that enthages him, (Pratiwinindya, 2018).

Such is also the case for the philosophical values of the decorative art of wuwungan particularly in the traditional house of Kudus. We have to perceive such a tradition based on the history. The history of the art and tradition is the entrance for us to disclose the philosophical values of the society. It means that traditional art is supported and developed by traditional societies (in oral tradition that expresses artistic values through voice, movement, or oral context) (Sutrisno, 2006). We have known that houses in the northern coastal areas, including the traditional house in Kudus, with their unique and exclusive ornaments, has undergone acculturation with cultures of Hindu, Buddha, China, Islam, and Europe.

The collapse of Majapahit in the first quarter of the 16th century and the emergence of Islamic power around Demak signified the end of the prehistoric era of Hinduism and the beginning of the Islamic middle ages. Islamic society in Java turned into a stronger power. They derived from the lower to middle classes of people in the northern coastal area of Java. Therefore, in 1527, Majapahit fell under the power of Demak (Gustami, 2007). The development of the new kingdom was accompanied by the development of houses for the royal families and the common people. Their traditional houses referred to the previous shapes of houses. The traditional house of Kudus represents such an acculturation and the establishment cannot be separated historically from the existence of the old Tajug. Tajug is the former name of the area which is now called Kudus (Said, 2019).

The existence of the decorative art of wuwungan in the traditional houses in Kudus is inseparable from the history of Demak kingdom. The establishment of Demak kingdom was initiated by the religious mission of some Islamic religious teachers to spread the Islamic teaching throughout Java. The teachers were then known as "wali songo" (the nine pious Islamic leaders). When spreading the Islamic teaching in Java, the walisongo focused their activities in Demak. With the support of the walisongo, especially based on the instruction of sunan Ampel, Raden Patah was assigned to spread Islamic religion and open a pesantren (traditional Islamic boarding school) in the village of Glagah Wangi. Not long after that, many people came to the village. This village grew into the center of knowledge and religion and later it also grew into the commercial center and finally became the center of the first Islamic kingdom in Java. The town was very popular in the history of Java since it had an advantageous location at the northern coastal area and was protected by mount Muria (Koentjaraningrat, 1984). 
Our knowledge on Javanese culture and architecture has mostly referred to the culture of the hinterland (Nagarigung) while ignoring the culture of the coastal areas. The definition proposed by Koentjaraningrat indicates that we have focused our paradigm on the Javanese kingdoms in Solo and Jogya which were historically included in the kingdom of Mataram. The agriculture-based feudal culture and the syncretic Islamic teaching stand out as if they represent Javanese culture. The architectural shapes of joglo houses of the kings and the royal families have been referred in the development of Javanese houses. On the other hand, the coastal culture, being one of the various cultures in Java, has a unique and interesting character based on the local condition. Such is also the case of the building architectures. Kudus is one of the coastal areas with unique cultural characteristics.

The people of Indonesia are predominantly Muslims. The relationship between the majority of Indonesian people and the Chinese people is based on the religion held by the Chinese people. It is perceived that Chinese people are not closely associated with Islam. Therefore, most Muslims perceive Chinese people as non-Muslims, whereas in the history of Islamic development in Indonesia, Islam and China had a close association. For example, the first king of Islamic kingdom named Raden Patah was actually a Chinese named Senopati Djim Bun. According to the Chinese source, the name Djim Bun derived from the Greek's word strong (Gustami, 2007).

Initially, the Kudus Traditional House was exclusively owned by Islamic Chinese merchants. In the 15 th century, the Chinese people in the coastal areas of Java generally were Muslims and developed their own mosques (Lombard, 2000). However, many indigenous local merchants developed their own traditional houses when their business developed. The Kudus Traditional Houses were mostly developed before 1810 and used to be the symbol of glory for the owners. Kudus traditional house is often called "joglo pencu" is a traditional house located in the Kudus Regency area as a typical Kudus house (Figure 1). Rumah Tradisional Kudus has its own speciality, namely in addition to the shape of joglo, all architectural elements are filled with decorative. The use of decorative varieties has been very familiar with human life for a long time. The decorative variety is not only as a decoration but has the meaning of symbols attached to the Holy society (Arifin, 2014).

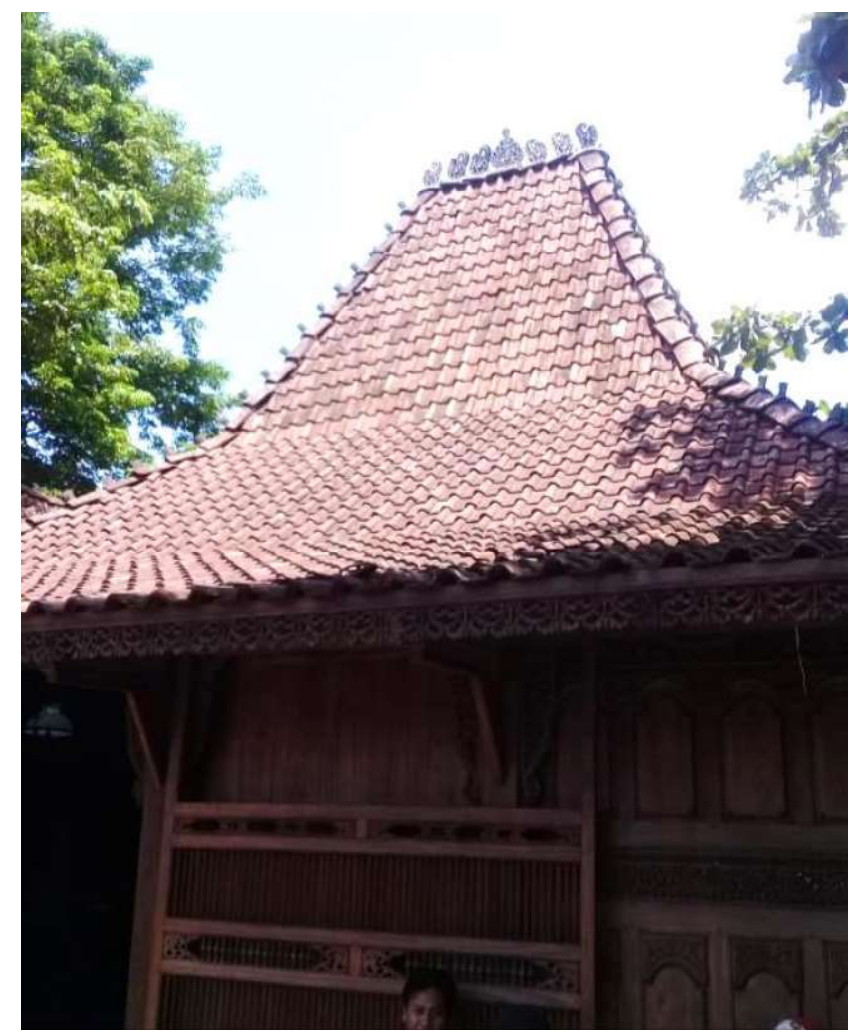



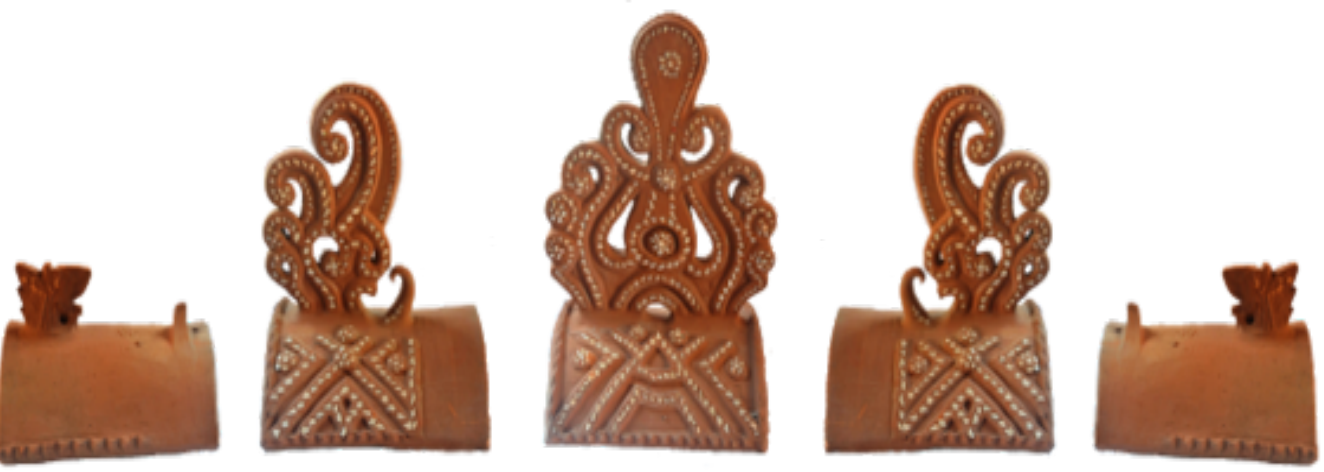

Figure 1. Kudus Traditional House "Joglo Pencu" with Decorative Art "Wuwungan" in Kretek Kudus Museum (Photo Suharson, May 15, 2020)

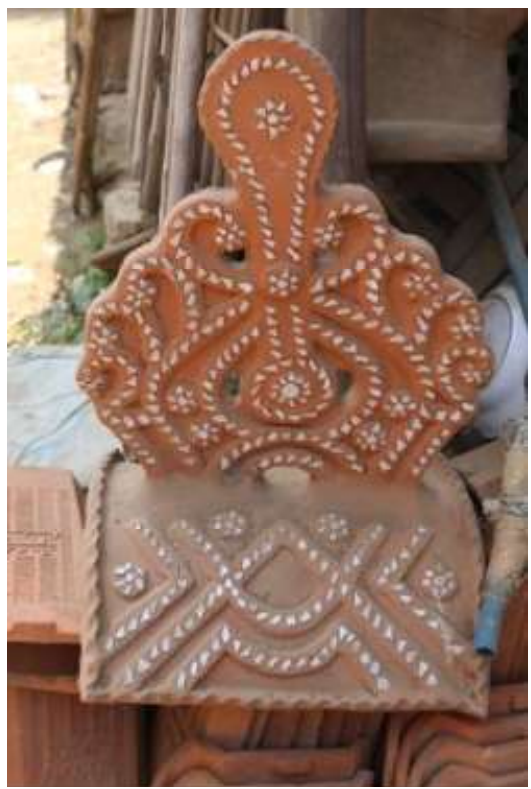

Figure 2. Wuwungan Ornamental Art in the Middle of the Roof of Kudus Traditional House "Wuwungan Rojo" (Photo Suharson, May 15, 2020) 


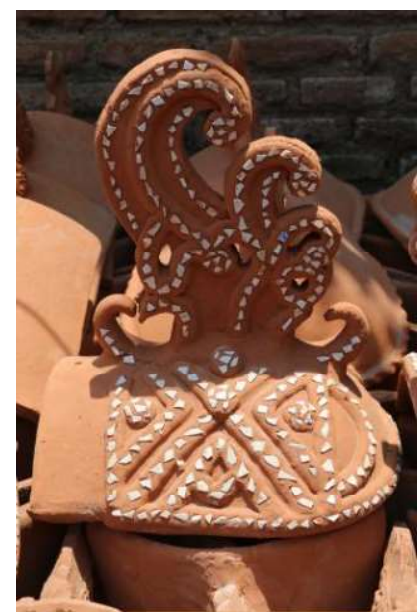

Figure 3. Wuwungan Ornamental Art Placed on the Right-Left Side of the Middle Wuwungan "Wuwungan Pengapit" (Photo Suharson, May 15, 2020)

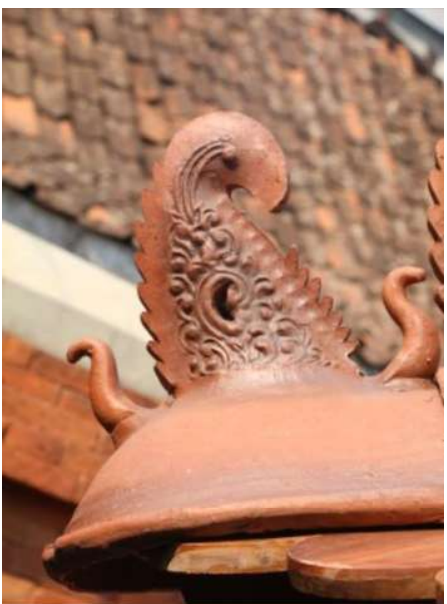

Figure 4. Wuwung Ornamental Art Placed at the Top or Bottom Corner as a Lock or Placed at the Most Corner in the Traditional House Kudus "Wuwungan Bulusan" (Photo Suharson, May 15, 2020)

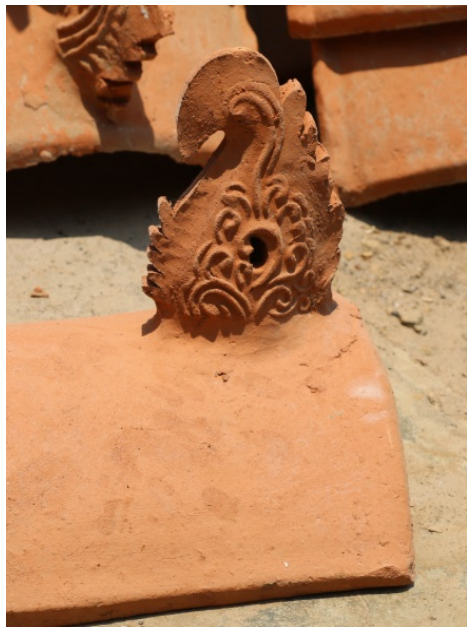

Figure 5. Wuwung Ornamental Art Placed on Four Sides that Form the Roof of the "Joglo Pencu" From Top to Bottom in the Traditional House Kudus "Wuwungan Jengger/Gelung Cekak"

(Photo Suharson, May 15, 2020) 
One of the factors that makes the Kudus traditional houses unique and exclusive is the carving of the house elements. According to the local people, the carving art of Kudus was taught by a Chinese named The-Ling-Sing who was thought to have lived in the kampong or village of currently named Sunggingan, long before Ja'far Shadiq (Sunan Kudus) arrived. According to Solichin Salam, the word Sunggingan derived from the Chinese word Sun Ging An. He was a Muslim immigrant. With Kyai Te-Ling-Sing, he came to Kudus. In addition to becoming a preacher, he was also skillful in the carving art. The word sunggingan also refers to carving. Therefore, doing sunggingan means doing the carving (Salam, 1994).

The shapes of the decorative art of wuwungan in Kudus Central Java is inseparable from the existence of previous cultural elements. Hindu religion also influenced the innovation of the overlapping roof shapes that resemble a mount (Meru). Later, the shape was developed by applying the carving popularly practiced in Jepara. The idea of carving likely referred to the carving in the graves behind the Kudus tower. The application of the overlapping roof model was closely associated with the brilliant aesthetic inspiration of Wali Songo who based the development on the psychology of Javanese people. In the memory of Javanese people, they still remember the glory time of Hindu Majapahit. The shape of Joglo, which is the typology of Majapahit palace, with the roof looking like a mount, is the roof model used in the development of mosques and graves. The palace in Islamic era, including the development of mosques and graves is also oriented to the concept of mount, meru, or arga that represents high places. Therefore, palace has a building named siti hinggil, which means a holy high place on which the king receives the pisowanan (call on) of the people.

The concept of residential building development in the region of Kudus results from the acculturation of the local people and the immigrants. Such an acculturation has led to the creation of strong building arts to represent the social status of the people. It signifies the upper economic status. Therefore, they build more luxurious houses than the houses of the common people. Accordingly, they need some craft art attributes to show off their prosperity. The specificity of decorative art of wuwungan in the region of Kudus, which is absent in other regions has uniquely characterized their culture. They put wuwung rojo (Figure 2) at the rooftop in the middle and on the left and right of wuwung rojo they applied the wuwung pengapit (Figure 3 ) in the shape of sulur/suluran ornamented with glass mosaics.

The decorative art of wuwungan at the rooftop is arranged either side by side or face to face. The position of wuwung rojo is in the middle of them. It describes the position of leather puppet show. Therefore, the decorative art of wuwungan is also popularly known as wuwung wayang. The face-to-face position of puppets at the right and at the left describes the figures in the leather puppet show. The wuwung rojo in the middle represents gunungan of the puppet. Meanwhile, according to the people, the shape of jengger may represent the red cock's head normally called jengger or gelung cekak (Figure 5). The Jengger is placed at the top of the roof tiles above the blandar that supports the blandar penuwun. The application of the jengger shaped rooftop at the blandar that supports the 4 blandar penuwun. And wuwungan bulusan (Figure 4) is applied to the corner of the roof or locking wuwungan, both above and at the bottom end. The puppet art in Javanese culture has been integrated and manifested in the aesthetic life visualized in the shapes of artistic ornaments such as the decorative art of wuwung. The shapes of mahkutho, gelung supit urang, and gunungan have inspired the creation of decorative art for the people of Kudus Central Java. They create the decorative art of wuwungan in that place although some people say that the idea of the creation of wuwung Kudus derive from the shape of tobacco leaves. They add glass mosaics on the sketched drawing to artistically decorate the wuwungan. This creation is expected to express such impression of beauty and grandiosity.

In their daily life, Javanese people have meaningful messages in the form of sanepa. They use the artistic works as a pepiling and teaching for the next generation (Herusatoto 2001). Essentially, the decorative art of wuwung Kudus has some philosophical values to be followed by the next generation of Javanese society. In this case, the people learn the concept of aesthetics and ethics in the social life in their attempt to maintain ideal human relationship with God. Javanese people believe in supernatural power that will always provide humans with the fundamental power. Such a power is invisible, yet it is perceived to be real.

The philosophical values of the Kudus traditional houses are maintained in the development of Javanese Joglo houses decorated with the artistic wuwung in the shape of royal crown ornamented with the glass mosaics. When we observe further, the decorative art serves more than just an ornament. As is the case of a shirt, a house also has some accessories to beautify the appearance. Ornaments in Javanese culture is intended to result in pleasure for the owner. In addition, it is also improves the beauty and religiosity. It describes the beautiful and comfortable paradise. The decorative art of wuwung symbolizes the holy mount replicated in the shape of the house's rooftop. Metaphorically, it is the highest point of the earth. However, it is also the "imaginary" point of the beginning and the end of creation. Life starts from and ends to this point. Such is the case of the puppet story 
in which we usually find a gunungan (mount) representing the beginning and end of the leather puppet show.

The position of the decorative art of wuwung between the uppermost of the house (wuwung, roof) and the sky (awang) represents the encounter of the wwang or wong (human) and the beautiful creation. As a part of an omah (home), the peak of the house represents the point to which human's panyuwunan or panuwunan (expectation) is directed. A house represents human's body located in the middle world. Meanwhile, the house foundation (palemahan) is the foundation of the whole construction, which is associated with the earth or lower world. The decorative art of wuwung at the peak of the omah (house) unites the sky and the earth. Wuwungan is the rerenggan (ornament) symbolizing the in-depth contemplation about a condition. This condition is described through peak symbols such as in cultural products of keris, kayon (gunungan), temple, mosque (mustoko), and stupa. The symbols used in wuwungan reflects the basic values in human's life in their "utmost" position since it is associated with the noble values that support their life (Musman, 2017).

"Three Universes" The Concept of Tri Loka Buana in The Kudus Traditional House

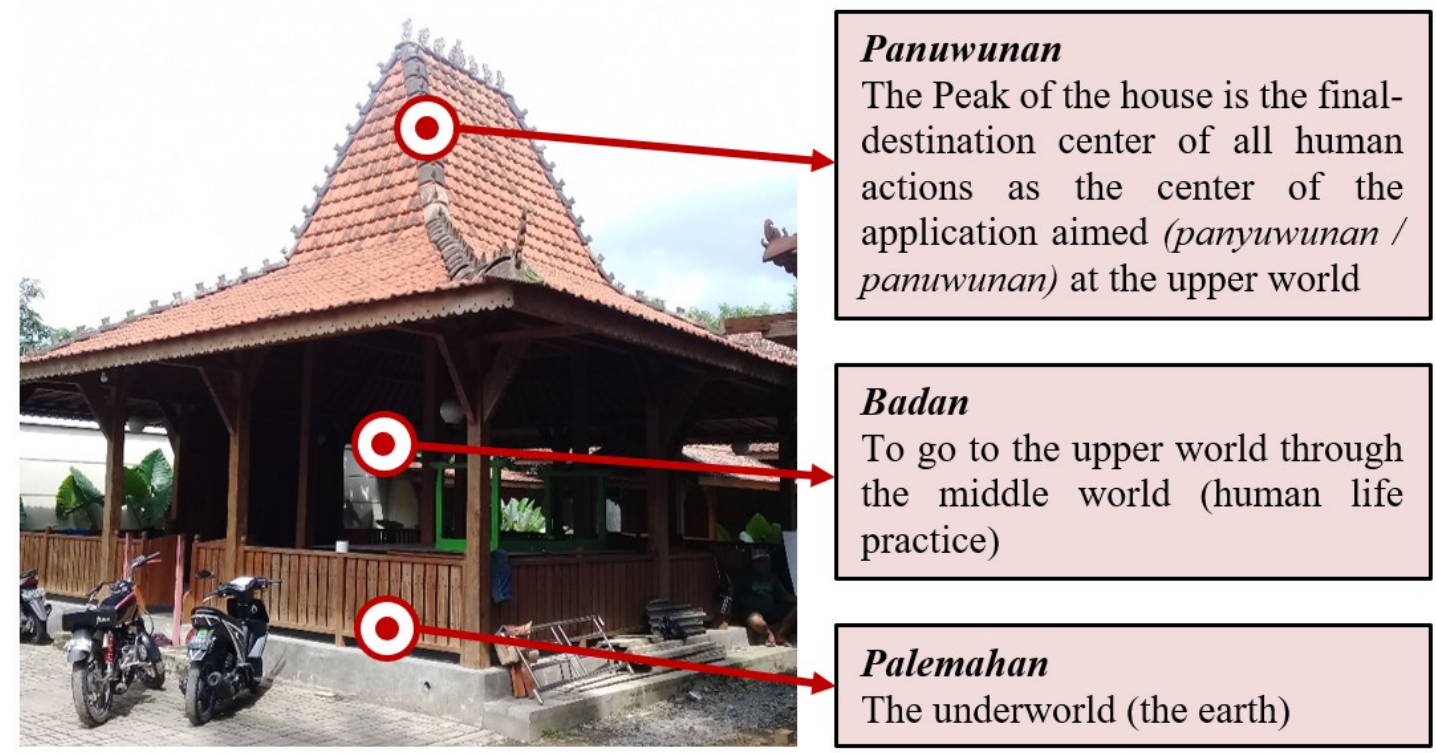

Figure 6. The Concept of Top-Middle-Low World in Kudus Traditional House Source: (Dharsono 2017)

Further, Dharsono (2016) suggested in his book Kreasi Artistik 2016 that the idea of mountain is consistently visualized and written. In the culture of Hindu and Buddha, a mount represents an analogy of the interrelation between the micro cosmos and macro cosmos. With many mounts in the natural environment in Java, it seems that the existence of mounts has inspired the religious perspective about mount. In Indonesian societies, particularly in Java, there is an objective and accurate reality that Indonesian societies mostly adored mounts. There are hundreds of active and inactive mounts throughout the country. Tall and grandiose mounts with their mythical mystery are perceived to have supernatural power. Accordingly, they are sacred. The perception that mounts are sacred has resulted in the emergence of some myths and worship to mounts. It also leads to the creation of mount prototype and replica (gunungan). The concept of mounts and trees is integrated to the upper, middle, and lower worlds. The upper world is the divine world in which the spirits of the ancestors live in ancient belief. It is differently referred to Kahyangan or nirvana (Hindu-Buddha), and Surga or paradise (Islam). The middle world represents the intermediate world (medium) of the upper to the lower worlds. Meanwhile, the lower world represents the earth and the properties therein (Dharsono, 2017).

From the abovementioned description, it is clear that the development of the traditional houses in Kudus with their decorative art of wuwung refers to the ancient culture (Hindu-Buddha). However, it has also been influenced by the Islamic culture. The essence of the art is that it describes the upper world in the form of the 
beautiful decorative art of wuwung ornamented with some glass mosaics. This symbol implies that humans expect to live in the paradise which in the decorative art it is visualized in the decorative art of wuwung, which is such beautiful and quiet as the paradise.

The life concept of Gusjigang which stands for bagus (nice), ngaji (recite Quranic verses), and dagang (commerce) among the people of Kudus has been manifested in the shape of the local traditional house. The decorative art of wuwung is therefore differently visualized from other shapes of wuwung in other regions in Java. As the main commercial line in the northern coastal area, Chinese merchants very strongly influenced the creation of the decorative art of the wuwung ornamented with glass mosaics. Islam also influenced the local culture of Kudus because Demak kingdom, a strong Islamic kingdom in Java, had a strong influence to the Islamic life of the people. During that period, realistic visualization of such living creatures as humans or animals in the decorative art of wulung was strongly prohibited. Islam forbids visualization of such living figures. Therefore, they introduced the decorative art of wuwung in the shape of sulur-suluran ornamented with glass mosaics.

Instead of using the clear and transparent glass mosaics, they used the white glass to imply the sincerity and purity in the religious service to God the Almighty. Human life begins from earth and ends in earth as well. It has been stipulated in the holy Quran that humans are created from a clot of soil. Such this belief is manifested when they develop a house. Therefore, they use earthen roof tiles and rooftops to remind humans about their existence in the world. It contains a highly philosophical value and has influenced Javanese people's mindset and behavior. It is implied that the highest wisdom, which is the highest philosophical value, is knowledge about God the Absolute in His relation with humans. That is the core of Mystical Philosophy (Dharsono, 2017).

\section{Conclusion}

The traditional house of Kudus refers to the previous shapes of house. Hindu and Islamic cultures have influenced the development of the traditional house. Over time, the development of traditional house in Kudus is also influenced by the European, Persian, Gujarat, and Chinese cultures as reflected in the ornaments of the decorative art of the wuwung (rooftop) in Kudus traditional houses. The decorative art also symbolizes the social and economic status of the people in Kudus.

The decorative art of wuwung on the rooftop of the traditional house in Kudus Central Java has philosophical values. Instead of using the clear and transparent glass, they use white glass to symbolize the purity and sincerity when we have a religious service to God the Almighty. The decorative art of wuwung Kudus has become a cultural characteristic of Kudus people. It has some philosophical values to guide the learning and the adoption of local genius in order that the Javanese people uphold highly good manners. Such those noble values lead to the improved belief to the great power of God the Almighty.

Wuwungan ornamental art in Kudus traditional house is closely related to the traditional culture whose manifestation is a symbolization of the culture that remains preserved and continued as a legacy of tradition. Likewise, the creation of wuwungan ornamental art in Kudus traditional house is very closely related to the meanings of the symbol. Its creation is well considered and carefully considered, so that its presence in addition to fulfilling aspects of function and demands of beauty also contains meanings that are in harmony with the intrinsic life expectancy. The well-being and peace of life seems to be the main goal to be achieved as a handle and belief in true life.

\section{Acknowledgements}

Pemerintah Kabupaten Kudus Kantor Kesatuan Bangsa dan Politik on recommendations to conduct the research, all leaders at the Indonesian Institute of The Arts Yogyakarta who have provided support and permission to study the Doctoral program at the Indonesian Institute of The Arts Surakarta. The interviewees of the Museum of Jenang Kudus, Museum of Kretek Kudus, Yayasan Mandala Kudus, and the Minaret of Kudus for collecting research data information, Practitioners, academics, and respondents from the Kudus Community, especially Kudus Kulon for information that enriches the study in research.

\section{References}

Arifin, Z., 2014. Makna Simbol Ragam Hias Pada Gebyok Rumah Tradisional Kudus. Disprotek, pp. 44-60.

Dharsono, 2016. Kreasi Artistik: Perjumpaan Tradisi Modern Dalam Paradigma Kekaryaan Seni. Karanganyar: 
Citra Sains Lembaga Pengkajian dan Konservasi Budaya Nusantara.

Dharsono, 2017. The Revitalization of Value of Cultural Precepts in Traditional Javanese Arts. The International Institute for Science, Technology and Education (IISTE).

Dhuhri, S., 2018. Islamic Arts and the Expression of Theology: Acehnese Traditional House, Its Ornamentation and Figurative Motifs. Wacana Seni Journal of Arts Discourse, pp. 1-39.

Gustami, 2007. Butir Butir Estetika Timur: Ide Dasar Penciptaan Seni Kriya Indonesia. Yogyakarta: Prasista.

Herusatoto, B., 2001. Simbolisme Dalam Budaya Jawa. Yogyakarta: Hanindita Graha Widia.

Ismail, N. H., Yunus, S. K. \& Surat, M., 2016. The Design of the Negeri Sembilan Traditional House that is Influenced by Customs and Regional Factors. Wacana Seni Journal of Arts Discourse, pp. 113-136.

Koentjaraningrat, 1984. Kebudayaan Jawa. Jakarta: PN Balai Pustaka.

Lombard, D., 2000. Nusa Jawa Silang Budaya Jilid II. Jakarta: PT Gramedia Pustaka Utama.

Mulder, D. C., 1970. Java Religie en Kunst: de Religie van Java. Amsterdam: s.n.

Musman, A., 2017. Filosofi Rumah Jawa. Yogyakarta: Pustaka Jawi.

Nasution, S., 2005. Buku Penuntun Membuat Tesis, Skripsi, Disertasi. Jakarta: Bumi Aksara.

Pratiwinindya, R. A., 2018. Simbol Gendheng Lanangan Pada Atap Rumah Tradisional Kudus Dalam Perspektif Kosmologi Jawa-Kudus. Imajinas, pp. 17-24.

Ronald, A., 2005. Nilai-Nilai Arsitektur Rumah Tradisional Jawa. Yogyakarta: Gadjah Mada University Press.

Said, N., 2019. The Minaret of Kudus. Yogyakarta: Idea Press.

Salam, S., 1994. Kudus Selayang Pandang. Kudus: Menara Kudus.

Soedarsono, R., 1999. Metodologi Penelitian Seni Rupa dan Pertunjukan. Bandung: Masyarakat Seni Pertunjukkan Seni Indonesia .

Soekiman, D., 2000. Kebudayaan Indis dan Gaya Hidup Masyarakat Pendukungnya di Jawa Abad XVIII-Medio $X X$. Yogyakarta: Yayasan Bentang Budaya.

Sutrisno, M., 2006. Oase Estetis: Estetika Dalam Kata dan Sketza. Yogyakarta: Kanisius.

Utomo, T. P. \& Subiyantoro, S., 2012. Nilai Keraifan Lokal Rumah Tradisional Jawa. Humaniora, pp. 269-278.

Arif Suharson was born in Bantul, June 22, 1975. He is currently taking the Arts Doctoral Program at the Indonesian Institute of the Arts Surakarta. He is active as a lecturer and has served as chairman of the Faculty of Visual Arts, Indonesian Institute of the Arts Yogyakarta. Arif is the author of books entitled "Teknik Putar Tradisional Gerabah, Proses, dan Finishingnya" and "Reproduksi Keramik"

Dharsono is a Professor at Postgraduate Program of Indonesian Institute of the Arts Surakarta. He was born in Klaten, July 14, 1951. He received his Bachelor degree from Faculty of Art, Institute of the Arts Surakarta, Indonesia. Then, He received his Master degree from Faculty of Design, Bandung Institute of Technology. His research interests are in the area of art history, art and humanities, conservation, philosophy of science, visual arts, and performing arts.

Bambang Sunarto is a lecturer at Postgraduate Program of Indonesian Institute of the Arts Surakarta. He was born in Salatiga, March 26, 1962. He received his Bachelor degree from ASKI/STSI Surakarta and he received his Master degree from Indonesian Institute of the Arts Surakarta. His research interests are in the area of philosophy, music, performance arts, and visual arts.

Nanik Sri Prihatini is a Professor at Postgraduate Program of Indonesian Institute of the Arts Surakarta. Her research interest is in the area of performing arts and dance arts. She is the author of books entitled "Seni Pertunjukan Rakyat Kedu". In addition, Nanik has 3 patents, namely Dolalak Purworejo, Seni Pertunjukan Rakyat Kedu, dan Dolalak Purworejo Dahulu dan Sekarang. 